\title{
The Impact of Dual Role Teaching Principals in Small Schools
}

\author{
Nitce Isa Medina, Azlin Norhaini Mansor, Jamalul Lail Abdul Wahab, Sharmini Siva Vikaraman
}

\begin{abstract}
Teaching principals exist in small schools. These principals have classroom responsibilities, administration duties, and educational instructor duties simultaneously. There are still some uncertainties on the dual role of school principals in small schools due to the lack of studies in this area. It is well-known that principals' instructional leadership practices are an imperative predictor to the success of small schools. Following this concern, the dual responsibilities taken by principals in small schools must be understood comprehensively. This paper discusses the excellent role of teaching principals in small schools. The objective of this qualitative research is to determine the dimensions of principal's teaching practices that influence the transformation of ordinary small schools into excellent small schools. Three principals in excellent small schools were interviewed and the themes that emerged from the interviews were matched with the dimensions drawn from the instructional leadership model used in this study. The results suggested that although a dual role teaching principal seemed to be burdened with responsibilities, the principals interviewed took the roles positively and excelled as instructional leaders. The teaching principals interviewed stated that their dual role increased their abilities in providing instructional leadership from many dimensions. The outcomes of this study may assist district school superintendents and preparatory program personnel in developing the right knowledge and in constructing a framework to support teaching principals in small schools in fulfilling their dual responsibilities.
\end{abstract}

Index Terms: Dual Role, Instructional Leadership, Teaching Principal, Small Schools.

\section{INTRODUCTION}

Compared to non-small schools, small schools are undeniably unique. One of the uniqueness is the enrolment of students. The Ministry of Education in Malaysia has defined small schools as schools with 150 enrolled students or less (Marzita \& Arbain, 2013; Ministry of Education, 2007; Mohd Yusoff \& Sufean, 2013; Zakaria, 2016). Most small schools are built to cater the education needs of primary school students living in rural and remote areas (Gardener \& Edington, 1982; Swift, 1984; Southworth, 2012; Reeves, 2003; Clarke \& Wildy, 2004; Tuck, 2009; Hyry-Beihammer \& Hascher, 2015; Kucita \& Maxwell,

Revised Manuscript Received on September 22, 2019

Nitce Isa Medina, Faculty of Education, Universiti Kebangsaan Malaysia, 43600 UKM Bangi.

Azlin Norhaini Mansor, Faculty of Education, Universiti Kebangsaan Malaysia, 43600 UKM Bangi.azlinmansor@ukm.edu.my

Jamalul Lail Abdul Wahab Faculty of Education, Universiti Kebangsaan Malaysia, 43600 UKM Bangi.

Sharmini Siva Vikaraman Faculty of Education, Universiti Kebangsaan Malaysia, 43600 UKM Bangi.
2016). The noble idea of wanting to improve the society does not exclude the principals in small schools from facing challenges. Aging building and infrastructures, lack of middle leader teachers, multi-grade teaching, financial constraints, and the dual role as a teacher and a principal are among the many real challenges faced by the principals in small schools. Also, principals in small schools must also be familiar with the different sociological and economic perspectives of working in small schools (Gardener \& Edington, 1982; Carter \& Keiler, 2009; Klar \& Brewer, 2014).

In Perak, there are 253 small schools and $90.5 \%$ of the schools are situated in countryside - estates, traditional villages, and small towns. Most of the schools have a long history, with some established during the colonial era. These rural schools are one of the tools used to develop a social network within the local community. Most of the principals agreed that the location of their school is strategic for the community to gain access to education (Zakaria et al., 2010). Small schools are pertinent to improve the local community, but such schools have a reputation of underperformance (Ministry of Education, 2012; Zalika, Faridah, \& Mohamad Johdi, 2009) that is partly due to the principal's leadership practises (Dolbasar, Shahril@Charil, \& Jamal@ Nordin, 2013). Small schools in Perak tend to have poor academic performance due to the students' socioeconomic factors (Azlin Norhaini et al., 2016).

Ideally, the small class size is advantageous. In a short class, teachers can give individual attention to their students, encouraging the students' academic improvement. (Wesley et al., 2000; Leithwood et al., 2004; In-Soo \& Jae, 2009; Nadzira et al., 2009; Nizamettin Koc \& Bekir Celik, 2015; Boguen, 2017). This idealistic view seems to miss its mark in small schools in Perak.

Previously, primary schools in Malaysia were ranked according to bands. The band was given based on public examination results and the school's own documentation. Band One was the highest band. Based on the statistics of school bands in 2016, there were only nine small schools in Perak that were awarded Band One by the Ministry of Education (Ministry of Education, 2017). These Band One small schools represent only about $3.5 \%$ of the overall number of small schools in Perak. Also, the analysis of public examination results by the Perak State Education of Department demonstrated that the student's academic achievement in Perak was relatively lower compared to the other states (Perak State Education of Department,

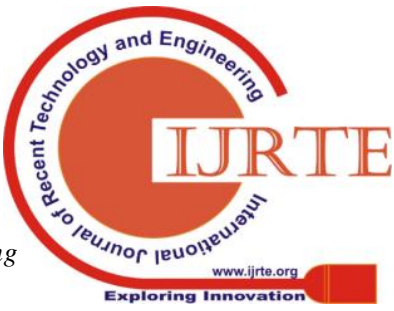




\section{The Impact of Dual Role Teaching Principals in Small Schools}

2014). Such a case is most probably caused by the failure of students to understand the teacher's teaching (Sharina et al., 2012). Apart from that, another study done in selected small schools in Perak showed that the leadership culture in small schools was unfavorable to the school's community and environment (Azlin Norhaini et al., 2016).

\section{LITERATURE REVIEW}

\section{A. Dual-Role Teaching Principals}

The principals in small schools have to carry out multiple tasks that are similar to rest of the schools, despite the small area of the school. These principals also act as teaching principals. At the time this paper is written, there is a lack of recognition on the challenges faced by these teaching principals who have to simultaneously manage the school and teach the students (Murdoch, 2009). The term 'teaching principal' is used to describe individuals who carry the responsibilities of educating, managing, and administrating at the same time (Murdoch, 2009; Clarke, 2002). Naturally, small schools lead to a small number of teachers. The lack of teaching staff forces the principal to become one of the subject teachers, making it a norm in small schools to have teaching principals. Apart from that, most principals in small schools also have more teaching hours per teacher, compared to the teachers in non-small schools. (Zainudin \& Ismail, 2007).

Other than the dual role, small school principals have to face the shortage of experienced teachers who have the potential to become a school leader (Grady, 1990; Hatton, 2001; Southworth, 2012; Clarke \& Wildy, 2004; Zainudin \& Ismail, 2007; Ewington et al., 2008; Khuan, Wan Salmuni \& Omar, 2009; Murdoch, 2009; Tuck, 2009; Newton \& Wallin, 2013). Apart from that, the lack of teaching staff also requires the available teachers to teach many subjects and to manage after-school programmes (Smit, Hyry-Beihammer, \& Raggl, 2015). Such a heavy workload adds more instructional burden to teachers and teaching principals.

From the previous observations, it was observed that insufficient period for instructional leadership, lack of professional preparation and support were the main concerns of teaching principals (Murdoch \& Schiller, 2002). The principals also reported feeling unsatisfactory to deal with resulting pressures and problems connected with instructional leadership, management, values, and expectations (Lashway, 2003; Wildy \& Clarke, 2005). Despite these concerns, the teaching principals in small schools perceived that their dual role enriches their relationships with others, lends credibility to their teaching or leadership efforts, and enables them to structure the administration within contexts that are both challenging and highly rewarding (Wallin \& Newton, 2013). Their responsibilities also help to increase their confidence and self-esteem (Southworth, 2012).

\section{B. Instructional Leadership Practices}

Leadership in small schools is complicated. This factor requires the attention of researchers and policymakers (Clarke \& Wildy, 2006; Ewington et al., 2008) as a small school principal's leadership practice is uncertain (Clarke, 2002). This uncertainty may be due to multiple specific challenges (Catterson, 2017) that must be addressed by small school principals as the instructional leader, compared to non-small school principals (Clarke \& Stevens, 2009). On the other hand, it was found that a principal must demonstrate high an internal locus of control and confidence for successful management (Hoog \& Johansson, 2005).

The core feature of instructional leadership emphasizes on the principals' direct engagement with the teaching and learning process (Bossert et al., 1982; Hallinger \& Heck, 1996; Hallinger \& Murphy, 1985). As perceived, teaching principals tend to be involved and spent more time in classrooms compared to other teaching staffs (Webb. \& Vulliamy, 1996; Williamson \& Galton, 1998). Being a teaching principal offer opportunity for best practices in instructional leadership that leads to school effectiveness (Mortimore, 1993; Neuman \& Simmons, 2000). Note that the principals' instructional leadership affects the excellence of a student's academic progress (Bosert, 1982; Ylimaki, 2007; Shahril @ Charil, Rahimah \& Hussien, 2010; Sahin, 2011; Valentine \& Prater, 2011; Zakaria, 2016).

Previous studies have reported that principals must possess certain qualities as a school leader. Southworth (2012) in his finding noted that successful small school principals are extra hard working, positive in all circumstances, team builders and players within a small group of school employees, school improvers despite the area of the school, and instructional leaders. The attributes of a successful small school principal stated here are supported by a detailed investigation by Azlin Norhaini et al. (2016) that revealed that most of underperformed small schools in Perak lack leadership and management strategies, causing a deficiency in motivational and pedagogical competencies among teachers.

Scholars like Duyar et al. (2013) found that a principal who emphasises more on instructional practice rather than managerial job would positively influence a teacher's ability to complete planned instructional goals. Teaching principals create time and space for the principal to easily practise Professional Learning Community (PLC) with their teachers. The PLC allows the principal to share their skills and knowledge with the teachers, especially if the subjects are similar. Initially, PLC as a teaching method was introduced to encourage sharing of skills and knowledge among teachers and as a medium to solve concerns associated with learning and teaching.

The combination of pedagogical and content knowledge between a teaching principal and teachers during teaching and learning process demonstrates excellent instructional leadership support by the principal. The support includes practising new pedagogical knowledge, upgrading existing knowledge, and accountability towards 
student's academic achievement. Such valuable support will encourage teachers to be prepared to apply various instructional strategies in teaching and learning (Mehmet Sukry \& Yan Liu, 2017). Despite the available literature, the role of teaching principals in excellent small schools as instructional leaders are still unclear. To fill this gap, this research was conducted based on the instructional leadership model as shown in the following fig. 1.

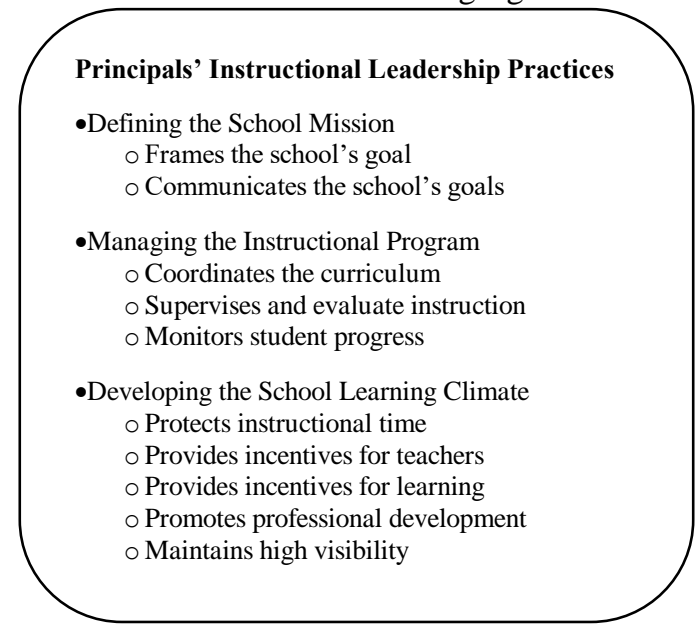

Fig. 1: Instructional Leadership Model by Hallinger, Wang, Chen, \& Li (2015) and Hallinger, Wang, \& Chen (2013).

Fig. 1 shows the principals' instructional leadership responsibilities are drawn from three dimensions in a conceptual framework suggested by Hallinger, Wang, Chen and Li (2015) and Hallinger, Wang and Chen (2013). This model was originally derived from a model that was developed by Hallinger and Murphy (1985). The first dimension, 'Defining the School Mission', discusses the principal's role in defining the zones and resources that the school will concentrate on. It is comprised of two sub-dimensions, which are 'frames the school's goal' and 'communicates the school's goal'.

The second dimension, 'Managing the Instructional Program', emphases on the synchronization and the control of guideline and syllabus. This dimension is comprised of further sub-dimensions - 'coordinates the curriculum', 'supervises and evaluates instruction', and 'monitors student progress'. The last dimension, 'Developing the School Learning Climate', confirms the perception that successful schools require the development of extraordinary principles and expectations that rewards constant improvement and learning. The last dimension is further categorised with 'provides incentives for teachers', 'protects instructional time', 'maintains high visibility', 'promotes professional development', and 'provides incentives for learning'. The size and conditions of the school demands increased focus on the area of specific leadership structure (Catterson, 2017) or practice that can be effectively applied to small schools. This research was conducted to assess the influence of teaching principals' best practices as an instructional leader in small schools. This study will try to find the answers of the following research questions:

Q1: What are the dimensions in instructional leadership that are being practised by principals in excellent small schools?

Q2: How do the principals in excellent small schools carry out their dual role as a teaching principal?

\section{METHODOLOGY}

This is a qualitative study involving three principals from excellent small schools in Perak. All three principals were interviewed based on specific criteria that had been set, and they voluntarily agreed to take part in this study. The choice of the principals was based on purposive sampling; they served in small schools that were awarded Band for at least three years. Face-to-face semi-structured interview protocol set was utilized to acquire responses from the participants. Prior to each interview session, the participants had given their written consent and were well-informed about their right and research ethics.

Initially, the interview protocol was validated by experts in qualitative studies and content. All interviews continued almost 60-75 minutes and audio were digitally -recorded and transcribed. All transcripts were checked and verified through members' checked procedures before being analysed. Coding and theme analysis were conducted with the assistance of ATLAS.ti software. In general, the principals were asked about their practice as teaching principals and as the instructional leader in their respective small schools.

\section{FINDINGS}

All principals were male from two different districts in Perak. P1 and P3 were from small schools in Muallim district while P2 was from Perak Tengah district. One of them was from a vernacular Tamil school while the rest were from non-vernacular school. All of the principals had served the excellent schools for at least three years, with two of them being the first-time principal in the respective schools. None of them had attended any preparatory program such as the National Professional Qualification for Educational Leaders (NPQEL). Therefore, they did their job as principals through trial and error based on their experience as middle leaders in previous schools.

\subsection{Dual Role Teaching Principals}

The principals in small schools have a minimal say in the small number of teachers in their school. They have to consider teachers on maternity leave, attending long term courses or meeting, and cases such as an emergency or sick leave. The lack of teachers has forced the principals to volunteer as a subject teacher to prevent any disruption in the learning and teaching procedure. All three principals in this study volunteered to teach Year Six students with each of them taught major subjects (Science, English Language, and Mathematics). Teaching Year Six students require a lot of preparation as they are sitting for a public examination by the end of the year. Volunteering as a subject teacher proved that the 


\section{The Impact of Dual Role Teaching Principals in Small Schools}

teaching principals were practising the sub-dimension 'protects instructional time' from Dimension Three, 'Developing the School Learning Climate'.

Other than teaching the students, the principals were also involved in extra classes, and motivational talk organised for the Year Six students. P1 went beyond his job scope by becoming one of the speakers on Science subject for an educational workshop held at the district level.

"During my first posting until today, I would request to teach Science. Not only that, I would love to be given the opportunity to teach Year Six students. Never missed any of the opportunity to teach Year Six students so far" P1-24/04 (35-40)

"When I first come here, I had to teach them Mathematics while they were in Year Five...then I teach them again the following year so I need to prepare them for the public examination as well. I make sure I can catch up with them so none left behind..." P3-16/11 (666-668).

Furthermore, there are no Literacy and Numeracy Screening (LINUS) experts posted in small schools since 2014 due to the small number of students in the schools. The Literacy and Numeracy Screening or LINUS is a program set up to detect literacy and numeracy problems in students, especially from primary school. Unfortunately, lack of LINUS experts in small schools created friction among teachers in managing students with the LINUS problem. If the problem is not carefully taken care of, the school's reputation will be affected, especially when the students sit for the public examination. This situation made the principals to personally coach the students, noting that the school had a small number of teachers with their own packed timetable.

"We identified those students with LINUS problems. I make sure they can read and count since Year One. We asked those students to stay back after school and I divided them into two groups. One group for the beginner, another one for reinforcement. I am involved with both" P2-04/10 (283-288)

"The principal should know...identify who cannot read, who are very weak in the calculation. We identify and we assist the students. Repeat and repeat. Inever condemn them for not knowing how to read. I called them, I asked them to do...more drills...even doing a very simple calculation. In the end, I know they can" P3-16/11 (795-800).

These principals also believed that there must be a good teamwork to achieve the schools' academic target. The principals ensure that all teachers must be involved in educational activities for students in Year Six. Teaching their students allowed the teaching principals to identify their students' academic problems and to monitor their academic achievement. These observations demonstrate that the teaching principals in this study practised the sub-dimension 'monitors student progress' under Dimension Two (Manages the Instructional Program).

\subsection{Instructional Leadership Practices}

The principals in this research were considering to set up a school mission and vision that is different from other schools. The emphasis of the school's mission and vision was the first step taken to improve the school's overall academic performance.

Previously, all excellent small schools in this study were categorised as low-performing schools. Such reputation reduced the school's yearly enrolment as parents prefer schools with a better reputation that is located only a few kilometres away from the respective small schools. Realising the negative label of low-performing schools, all three principals took the first step by stating the school's mission and vision clearly to the teaching staffs. The school's mission and vision were tailored to be achievable and were based on the students' academic achievement. P1 followed the documentation guidelines given by the ministry, namely the Standard Kualiti Pendidikan Malaysia (SKPM). This approach was taken to fulfil the requirement of a Band One. Meanwhile, P3 researched the characteristics of high-performing school as his school's guidelines. This is in line with the practice in the first dimension, 'Defining the School Mission'.

"I need to check my student's academic progress...then I announced it to the teachers. Always. I think we need to always emphasise the vision, mission...our target. Yes, we need to have the school's target in mind" P2-04/10 (94-96)

"...when I finished with our guidelines from the high performing school concept; I can see now what need to be done to make this school excel" P3-16/11 (436-438)

"We need to have a closer look at the document; we comply, we follow. The SKPM is there to guide us as an administrator. For example, it was stated in the documents on how to become Band One school. So, we follow the requirements" P1-24/04 (71-78)

Other than completing the schools' reports, the principals in an excellent small school also used the PLC approach in teaching and learning. P1 and P3 frequently observed their teachers and evaluated them to ensure that the quality of teaching met the high standards of the district level and state level education officers. By practising PLC and constant observation on the teacher's pedagogy, the principals can get closer to their teaching staffs while assisting in improving their teaching skills. Applying PLC to teachers portrayed the teaching principals as school leaders with the capacity to learn. This situation shows that the principals were practising the sub-dimensions 'promotes professional development' and 'maintains high visibility' under the third dimension, 'Developing the School Learning Climate'.

"Applying PLC enables me to share useful information with my teacher from time to time. It becomes mutual. There are times when I was the one who learn from my teacher. It is not like a formal, typical observation; I am not looking for their flaws..." P1-24/04 (412-416)

"Me and my teachers applied PLC quite a lot. Maybe because we feel more like siblings rather than colleagues. So, I can straight away check my teachers teaching aid material whether it is suitable or not...or maybe whether it needs some upgrades" P3-30/07 (231-237) 
Having small size schools also allowed the principals to monitor and observe the teaching and learning frequently. As stated by P2, he made sure that the size of the school became an advantage for him "I always enter the classroom while I go around the school. It is my routine. This is a small school anyway...it only takes a while. Whenever I enter any classroom, I make sure it will take about ten to fifteen minutes only..." P2-04/10 (310-319)

Apart from teaching Year Six students, the teaching principals were also needed to teach students in the multi-grade classroom. Multi-grade teaching was set up to accommodate a small number of students with different level of achievements and ages. In Malaysia, small schools practised multi-grade teaching by combining Year Two pupils with Year Three, and Year Four pupils with Year Five. This situation requires teachers to adjust their pedagogies accordingly based on the model of multi-grade teaching. Being teaching principals that allocate time to assist teachers' teaching and also teach the students reflected the practices of a sub-dimension from the Dimension Three (Developing the School Learning Climate), 'maintains high visibility'.

\section{DISCUSSION AND CONCLUSION}

Although the dual role as teaching principal seemed to be a burden to the principals in small schools, the observations demonstrated that the principals in excellent small schools in this study were never intimidated by the job scope. Instead, they positively took up the teaching job and tried their best to balance the role. In this study; all three teaching principals stated that their dual responsibilities increased their abilities to provide instructional leadership from many dimensions, confirming the finding from Wallin and Newton (2013). The emphasis on school mission and vision appeared to be the first step taken by all principals to lead the school in achieving better academic performance. This step is crucial to influence the mindset of other teaching staffs and pull them out of their comfort zone for the good of the school. These principals went out of their way to gather valuable insights, adjusted the school's vision and mission, and tirelessly worked according to the guidelines acquired.

The principals described that that teaching allowed them to be closer to their students. Due to the close relationship, the principals were able to identify their students' academic progress individually. Apart from that, their role as teaching principal gave them direct access to understand the problems regarding teaching and learning. All three principals in this study were able to identify their students with literacy and numeracy problems and took the initiative to overcome the problem by spending more time with them. This finding is consistent with Murdoch (2009), who stated that working collegially with teachers and knowing each student personally are some of the most rewarding aspects of their dual role.

Furthermore, the willingness of the principals to teach significant subjects for Year Six students demonstrated their attribute as a leader with accountability. The principals also took responsibility for the student's result and did not blame other teachers for a student's poor achievement. Apart from teaching Year Six students, there were times when the teaching principals were demanded to teach students in the multi-grade classroom. Khuan et al. (2009) stated that principals and teachers in small schools in Perak experienced burnt out due to excessive workload, which included teaching a multi-grade classroom. Teaching multi-grade students is considered to be challenging as there is a mismatch between the national syllabus with the need of multi-grade pedagogy (Makoelle \& Malindi, 2014). This mismatch is because the teachers in small schools were not professionally trained to teach multi-grade students in one classroom (Ali \& Salima, 2011; Taole \& Mncube, 2012; Kucita \& Maxwell, 2016).

Besides, the teaching principals were able to add value to the teachers' professional development by emphasising on the pedagogical methods and collaboration among them. The principals in small schools can directly observe and evaluate the teachers' competencies while playing an active role as teaching principals. Being a subject teacher provided a platform for the principals to demonstrate their credibility as an instructional leader and to monitor teachers in the classroom (Boyd, 1996; Leithwood et al., 2004). Practising frequent discussion with teachers and encouraging teachers' professional development are among the principals' instructional practices in excellent small schools. Regular conversations with teachers were achieved through classroom observations, while teachers' professional development was gained by applying the PLC method in schools. These practices were also used by the principals in successful schools. As suggested by Blase' \& Blase' (2000), Wahlstrom and Louis (2008) and Wallin and Newton (2013), principals should be able to encourage continuous reflections from the teachers by consistently giving suggestions and appropriate feedback through collegial dialogue.

Apart from that, the two-way communication between principals and teachers allowed for the exchange of ideas, suggestions, and responses about pedagogical and content knowledge. Such discussion will result in continuous reflections by the teachers on the teaching and learning process in the classroom. Apart from that, novice teachers, especially the inexperienced ones, can model their principals as a subject teacher. By modelling the principals, novice teachers will eventually increase their teachers' self-efficacy in teaching (Milner \& Hoy, 2003; Hoy \& Smith, 2007).

Dual role teaching principals offered the opportunity to the principals to shine as an instructional leader. Becoming a role model as an instructional leader enables the principals to lead by example. They managed to demonstrate their expertise by displaying good qualities as a teacher and as a subject matter expert. Being a teaching principal suggests that they were able to create a competent teaching and learning environment among teachers, improving the students' academic achievement. These principals proved their credibility through their dual role as 
teaching principal; simultaneously managing both the students and the school. Apart from that, a small school also allows the principals to monitor their teachers and students easily. The results of this study suggest that the instructional leadership role of principals is to ensure teaching quality and monitor student learning. The common strategy asserted by the principals to achieve this standard is to maintain a visible presence in classroom and school (Hallinger \& Walker, 2017) and allows direct involvement of principal as an instructional leader apart from monitoring the teacher's teaching and learning session (Leithwood et al., 2004).

The challenges faced by small school's principals are accentuated because the position is often filled with novice principals who have inadequate preparation for the complexities of the role (Clarke \& Stevens, 2006). The preparatory program, such as the National Professional Qualification for Educational Leaders (NPQEL) in Malaysia, should serve as an opportunity for future school principals to become an exemplary instructional leader. Based on this study, none of the principals in excellent small schools had gone to the preparatory program. They had been leading their own school based on the trial and error concept and based on past experience as middle leaders. Although they did not receive any formal training, their strong leadership attributes guided them in bringing the schools to their excellence. The principals in this study possessed credibility, accountability and high commitment attributes described by Shirrell (2015). The attributes indirectly demonstrate high self-esteem and an internal locus of control that helped to address challenging problems (Hoog \& Johansson, 2005).

Although it is a significant challenge to do justice to their dual role, teaching principals should take advantage of this role to facilitate teachers' teaching for the benefits of both parties. The mutual benefits gained by both principals and teachers proved that the effectiveness of rural small school principal could be improved by sharing instructional leadership knowledge with teachers, in addition to creating an environment that encourages teaching and learning (Nor Asikin, 2008). The sharing of expertise will consequently create a positive workspace.

The dual role of teaching principals was demonstrated to have a positive influence on the school. The teaching principals in small schools perceived that their dual role enriches their relationships with others, lends credibility to their teaching or leadership efforts, and allows them to structure the system within contexts that are both challenging and highly rewarding (Wallin \& Newton, 2013). The positive impact is likely to be strengthened with a clear portrayal of effective small school leadership values. More research is needed to get a better picture of the dual role of teaching principals in small schools. Future studies should conduct a range of different probes during interviews that may give more insights into the dual role and their instructional leadership practices. Apart from that, the exercises should also be evaluated from the perspectives of the small school's teachers too.

This research was supported in part of the 'Geran Galakan Penyelidik Muda' (GGP-2018-008) to the Educational Leadership and Policy Department at the Faculty of Education, Universiti Kebangsaan Malaysia.

\section{REFERENCES}

[1] Ali Nawab \& Salima Rahim Baig. (2011). The Possibilities and Challenges of Multi-grade Teaching in Rural Pakistan. International Journal of Business and Social Science, 2(15), 166-172.

[2] Azlin Norhaini Mansor, Habibah Rahim, Norliah Abdul Aziz, Mohamed Yusoff Mohd Nor, Aszhar Ramli, Mohd Khalid Mohamad Nasir, Mohd Izham Mohd Hamzah, Jamalul Lail Abdul Wahab. (2016). Laporan Faktor Penyumbang Utama Pencapaian Akademik Sekolah Rendah di Perak dan Strategi Terbeza Mengikut Konteks Ke Arah Meningkatkan Prestasi Sekolah. Institut Darul Ridzuan.

[3] Blasé, J. \& Blasé, J. (2000). Effective instructional leadership: Teachers' perspectives on how principals promote teaching and learning in schools. Journal of educational administration, 38(2), 130-141.

[4] Bouguen, A. (2017). Does Class Size Influence Student Achievement? Technical Report. DOI: 10.13140/RG2.2.17402.34249

[5] Bossert, S., Dwyer, D., Rowan, B., \& Lee, G. (1982). The instructional management role of the principal. Educational Administration Quarterly, 18(3), 34-64.

[6] Boyd, B. (1996). The principal as teacher: a model for instructional leadership. NASSP Bulletin, 80(580), 65-73.

[7] Carter, J.H \& Keiler, L.S. (2009). Alternative Certified Teachers in Urban Small Schools: Where Policy Reforms Meets the Road. Urban Rev. DOI 10.1007/s11256-008-0117-7.

[8] Catterson, F. M. (2017). Small Primary School Leadership Structures. Challenges and Evolution (Doctoral dissertation, School of Education)

[9] Clarke, S. (2002). The teaching principal: From the shadowlands to a place in the sun. Queensland Journal of Educational Research, 18(1), 23-37.

[10] Clarke, S. \& Stevens, E. (2006). Spatial engagement: The navigation of a novice teaching principal in a small rural community. Studies in Learning, Evaluation Innovation and Development, 3(1), 12-26.

[11] Clarke, S., \& Stevens, E. (2009). Sustainable leadership in small schools: Selected Australian vignettes. Journal of Educational Change, 10(4), 227.

[12] Clarke, S \& Wildy, H. (2004). Context Counts: Viewing Small School Leadership from the Inside Out. Journal of Educational Administration, 42(5), 555-572.

[13] Dolbasar Kasan, Shahril@Charil Marzuki \& Jamal@Nordin Yunus. (2013). Pelaksanaan Perancangan Strategik dan Faktor Penyumbang Terhadap Keberkesanan Sekolah Di Sekolah Kurang Berkesan di Malaysia. Management Research Journal, 2(1), 1-18.

[14] Duyar, I., Gumus, S. \& Bellibas, M. S. (2013). Multilevel analysis of teacher work attitudes: the influence of principal leadership and teacher collaboration. International Journal of Educational Management, 27(7), 700-719.

[15] Ewington, J, Mulford, B, Kendall, D, Edmunds, B, Kendall, L \& Silins, H. (2008). Successful School Principalship in Small Schools. Journal of Educational Administration, 46(5).

[16] Gardener, C. E. \& Edington, E.D. (1982). The Preparation and Certification of Teachers for Rural and Small Schools. Digest Number? New Mexico: ERIC Clearinghouse on Rural Education and Small Schools.

[17] Grady, M. L. (1990). The Teaching Principal. Research in Rural Education, 6(3), 49-52.

[18] Hallinger, P \& Heck, R. H. (1996). Reassessing the Principal's role in School Effectiveness: A Review of Empirical Research, 1980-1995. Educational Administration Quarterly, 32(5).

[19] Hallinger, P. \& Murphy, J. (1985). Assessing the instructional leadership behaviour of principals. Elementary School Journal, 86(2), 217-248.

[20] Hallinger, P., Wang, W. C., Chen, C. W., \& Li, D. (2015). Assessing instructional leadership with the principal instructional management rating scale. Assessing Instructional Leadership with the Principal Instructional Management Rating Scale. https://doi.org/10.1007/978-3-319-15533-3

[21] Hallinger, P., \& Walker, A. (2107). Leading learning in Asia-emerging empirical insights from five societies. Journal of Educational Education, 55(2), 130-146. 
22] Hallinger, P., Wang, W. C., \& Chen, C. W. (2013). Assessing the Measurement Properties of the Principal Instructional Management Rating Scale: A Meta-Analysis of Reliability Studies. Educational Administration https://doi.org/10.1177/0013161X12468149.

[23] Hatton, E. (2001). School Development Planning in a Small Primary School, Journal of Education Administration, 39(2).

[24] Hoog, J., \& Johansson, O. (2005). Successful principalship: the Swedish case. Journal of Educational Administration, 43(6), 595-606.

[25] Hoy, W. K \& Smith, P. A. (2007). Influence: a key to successful leadership. International Journal of Educational Management, 21(2), 158-167.

[26] Hyry-Beihammer, E. K., \& Hascher, T. (2015). Multi-grade teaching practices in Austrian and Finnish primary school. International Journal of Educational Research. http://dx.doi.org/10.1016/j.ijer.2015.07.002.

[27] In-Soo Shin \& Jae Young Chung. (2009). Class size and studen achievement in the United States: A Meta-analysis. KEDI Journal of Educational Policy, 6(2), 3-19.

[28] Klar, H. W \& Brewer, C. A. (2014). successful leadership in a rural, high poverty school: the case of County Line Middle School. Journal of Educational Administration, 52(4), 422-445.

[29] Khuan Wai Bing, Wan Salmuni Wan Mustaffa \& Omar Abdull Kareem. (2009). Facing Constant Challenges: Do Small Schools Have Workable Solutions? Proceedings $1^{\text {st }}$ Regional Conference on Educational Leadership and Management.

[30] Kucita, P., \& Maxwell, T. W. (2016). Multi-grade teaching in Bhutan: Congruency amongst policies, teacher education and practices. EIP Educational Innovation. 1

[31] Lashway, L. (2003). "Inducting School Leaders". ERIC Digest 170-August 2003: Clearinghouse on Educational Management. Available online http://eric.uoregon.edu/publications/digest/digest170.html.

[32] Leithwood, K., Louis, K.S, Anderson, S dan Wahlstrom, K. (2004). How leadership influences student learning. Executive Summary. Centre for Applied Research and Educational Improvement, University of Minnesota.

[33] Makoelle, T. M., \& Malindi, M. J. (2014). Multi-grade Teaching and Inclusion: Selected Cases in the Free State Province of South Africa. International Journal of Educational Sciences, 7(1), 77-86.

[34] Marzita Abu Bakar \& Arbain Pinni. (2013). Amalan Terbaik Pengurusan dan Kepimpinan Sekolah Kurang Murid (SKM): Keperluan dan Impak Agihan Bantuan Geran Per Kapita (PCG) Murid. Jurnal Pengurusan dan Kepimpinan Pendidikan, 26(2), 1-25.

[35] Mehmet Sukru Bellibas \& Yan Liu. (2017). Multilevel analysis of the relationship between principals' perceived practices of instructional leadership and teachers' self-efficacy perceptions. Journal of Educational Administration, 55(1), 49-69.

[36] Milner, H. R \& Hoy, A. W. (2003). A case study of an African American Teacher's self-efficacy, stereotype threat and persistence. Teaching and Teacher Education, 19, 263-276.

[37] Ministry of Education. (2007). Pelan Induk Pembangunan Pendidikan (PIPP) 2006-2010: Merintis Pembaharuan-Satu Misi Nasional. Kementerian Pendidikan Malaysia.

[38] Ministry of Education. (2012). Laporan Awal Pelan Pembangunan Pendidikan Malaysia. Kementerian Pendidikan Malaysia.

[39] Ministry of Education. (2017). Data Sekolah Kurang Murid Band Satu 2016. Sektor Bahagian Perancangan dan Penyelidikan Dasar Pendidikan. Kementerian Pendidikan Malaysia.

[40] Mohd Yusoff Mohd Nor \& Sufean Hussin. (2013). Demokrasi Pendidikan-Dilema Sekolah Kecil dan Sekolah Berpusat. Penerbit Universiti Malaya, Kuala Lumpur.

[41] Mortimore, P. (1993). School Effectiveness and the Management of Effective Learning and Teaching. Kertas Kerja dibentangkan di Annual Meeting of the International Congress for School Effectiveness and Improvement. Norrkoping, Sweden, Januari 1993.

[42] Murdoch, D. (2009). Teaching Principals in Smaller Primary Schools: Their Issues, Challenges and Concerns. TEACH Journal of Christian Education, 3(1), 32-37.

[43] Murdoch, D. \& Schiller, J. (2002). Teaching principals in smaller primary schools: Their issues, challenges and concerns. Paper presented at the Australian Association for Research in Education Conference, Brisbane, Australia.

[44] Nadzira Yahaya, Mohd Halim Kadri \& Naimah Ahmad Yahya. (2009). Class Size, Class Ranking and Students' Achievement. Ethics and Accounting Education 200.

[45] Newton, P. \& Wallin, D. C. (2013). The Teaching Principal: An Untenable Position or a Promising Model? Alberta Journal of Educational Research, 59(1), 55-71.
[46] Nizamettin Koc \& Bekir Celik. (2015). The Impact of number of Students per Teacher on Student Achievement. Procedia-Social and Behavioral Sciences, 177, 65-70.

[47] Nor Asikin Salleh. (2008). Model Sekolah Berkesan: Satu Kajian Sekolah-sekolah Kebangsaan Luar Bandar. Tesis Doktor Falsafah. Universiti Utara Malaysia.

[48] Neuman, M. \& Simmons, W. (2000). Leadership for Student Learning. Phi Delta Kappan, 82(1), 4.

[49] Perak State Education of Department. (2014). UPSR Result Analysis Document 2014

[50] Reeves, C. (2003). Implementing the No Child Left Behind Act: Implications for Rural Schools and Districts. Illinois: North Central Regional Educational Laboratory.

[51] Sahin, S. (2011). Relationship between Instructional Leadership Style and School Culture. Educational Sciences: Theory \& Practice, 11(4) 1920-1927.

[52] Shahrina Md. Nordin, Wan Fatimah Wan Ahmad, Yunus Mohd Nayan, Abdul Malek Abdul Rahman, Noraini Ismail, Noor Aini Ahmad \& Othman Mohd Yunus. (2012). Menjana Pembangunan Negeri Perak, Ke Arah Kecemerlangan Modal Insan. Perak. Emeritus Publications.

[53] Shahril @ Charil Marzuki, Rahimah Ahmad \& Hussien Ahmad. (2010). Kepimpinan Pengetua-Menjana Modal Insan Di Sekolah Berkesan. Selangor: PTS Profesional Publishing Sdn Bhd.

[54] Shirrell, M. (2015). New principals, accountability and commitment in low-performing schools. Journal of Educational Administration, 54(5), 558-574.

[55] Smit, R., Hyry-Beihammer, E. K. \& Raggl, A. (2015). Teaching and learning in small, rural schools in four European countries: Introduction and synthesis of mixed-/multi-age approaches. International Journal of Educational Research, 74, 97-103.

[56] Southworth, G. (2012). Lessons from Successful Leadership in Small School. Second International Handbook of Educational Leadership and Administration. Springer.

[57] Swift, D. (1984). Finding and Keeping Teachers: Strategies for Small Schools. Washington D.C: ERIC Clearinghouse on Rural Education and Small Schools.

[58] Taole, M. J., \& Mncube, V. S. (2012). Multi-grade Teaching and Quality of Education in South African Rural Schools: Educators' Experiences. Studies of Tribes and Tribals, 10(2), 151-162.

[59] Tuck, A. (2009). Small school's challenges-Learning Lessons from small school headteachers. Research Associate Summary. National College for School Leadership.

[60] Valentine, J. W. \& Prater, M. (2011). Instructional, Transformationa and Managerial Leadership and Student Achievement: High School Principals Make a Difference. NASSP Bulletin, 95(1), 5-30.

[61] Webb, R. \& Vulliamy, G. (1996). The changing role of the primary-school headteacher. Educational Management \& Administration, 24(3), 301-315.

[62] Wahlstrom, K.L \& Louis, K. S. (2008). How Teachers Experience Principal Leadership: The Roles of Profesional Community, Trust Efficacy and Shared Responsibility. Educational Administration Quarterly, 44(4), 458-495.

[63] Wallin, D. \& Newton, P. (2013). Instructional Leadership of the Rural Teaching Principal: Double the Trouble or Twice the Fun? International Studies in Educational Administration, 41(2), 19-31.

[64] Wildy, H. \& Clarke, S. (2005). "Leading the small rural school: the case of the novice principal". Leading and Managing, 11(1), 43-56.

[65] Williamson, J. C. \& Galton, M. (1998). Building a school culture.

[66] Wesley, P.A., Fine, M., Gladden, M., Holland, N.E., King, S.P, Mosak, E. \& Powell, L.C. (2000). Small Schools: Great Strides. A Study of New Small Schools in Chicago. New York: Bank Street College of Education.

[67] Ylimaki, R. (2007). Instructional Leadership in Challenging US Schools. ISEA 35(3), 11-19.

[68] Zakaria Kasa, Amir Hasan Dawi, Azhar Wahid, Mohd. Sanimadon, Mohd Nooridris \& Shaharudin Ali. (2010). Isu Pendidikan Luar Bandar di Perak. Final Research Report. Universiti Pendidikan Sultan Idris, Tanjong Malim, Perak

[69] Zakaria Othman. (2016). Kepimpinan Instruksional Guru Besar Sekolah Kurang Murid. Disertasi Ph.D. Universiti Malaya.

[70] Zalika Adam, Faridah Kassim \& Mohamad Johdi Salleh. (2009). Memperkasakan Pendidikan Luar Bandar. Prosiding Seminar Persidangan Kebangsaan Pendidikan Luar Bandar, 3-5 Februari 2009 di Kota Kinabalu, Sabah.

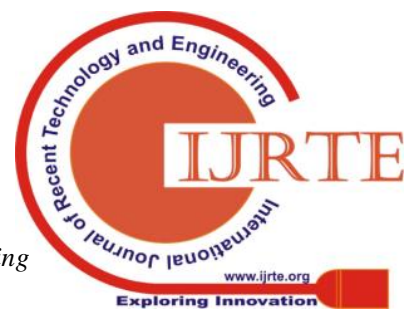


The Impact of Dual Role Teaching Principals in Small Schools

[71] Zainudin Abu Bakar \& Ismail Buang. (2007). Gemilang 7: Suatu Kegagalan atau Kejayaan Dari Sudut Proses Pengurusan Strategik? Jurnal Pendidikan Universiti Teknologi Malaysia, 12, 83-90.

\section{AUTHORS PROFILE}

My name is Nitce Isa Medina, currently working with Faculty of Education, Universiti Kebangsaan Malaysia, 43600 UKM Bangi. My area of interest is Teaching and Leadership.

I am Azlin Norhaini Mansor, and my current affiliation is with Faculty of Education, Universiti Kebangsaan Malaysia, 43600 UKM Bangi. My area of interest is Teaching and recruitment. For further details contact me.azlinmansor@ukm.edu.my

I am Jamalul Lail Abdul Wahab, and affiliated with Faculty of Education, Universiti Kebangsaan Malaysia, 43600 UKM Bangi.my interest area is Leadership.

My good name is Sharmini Siva Vikaraman and currently working with Faculty of Education, Universiti Kebangsaan Malaysia, 43600 UKM Bangi. My area of interest is Teaching. 